\title{
Online Learning: A View from Higher Education
}

Afzal Sayed Munna ${ }^{1^{*}}$, Dr. Anupam Mazumdar
${ }^{2}$ Lecturer, Module Leader and Academic Coordinator, University of Wales Trinity Saint David London, Winchester House, 11 Cranmer Rd, Vassal, London, UK SW9 6EJ

${ }^{2}$ Lecturer \& DBA supervisor University of Wales Trinity Saint David London, Winchester House, 11 Cranmer Rd, Vassal, London,

UK SW9 6EJ

\begin{abstract}
*Corresponding author: Afzal Sayed Munna
| Received: 13.02.2021 | Accepted: 27.02.2021 | Published: 08.03.2021 |

Abstract: The increased number of students, technological development, new learning theories and personal needs have led to the introduction of online learning and vis-à-vis learning from home. Online learning has recently been very popular (especially considering the COVID-19 situation and lockdown) and learning from home for everyone as they stayed out from the university and did home learning to keep them educationally updated. Almost every university in Britain and around the world has adopted online teaching using various technological tools to keep their pupils updated and ahead on the crowd. Most of the higher educational institutions also considered delivering their regular programmes online. While assessing the importance of home learning with the parents, it was evidenced that parents agreed on flexible learning (often refereed to online leaning and home learning) because they think online learning has made education effective, it has been considered as a motivation factor in terms of self-efficacy. However, from the personal experience of teaching and learning it was truly evidenced that there are lot differences between the traditional and online learning. In traditional learning the teachers have the full control on class management and to the learning environment. In traditional learning, the teacher's ability, personality, quality, adaptation, learning situation, and the creation of course materials affect the learning-teaching performance, which is quite different in online/e-learning situations. In this article, we are trying to address the approaches of learning in the higher education sector, including the concept of online learning and highlight some common obstacles. Keywords: COVID-19, higher education, online learning, learning from home.
\end{abstract}

\section{INTRODUCTION}

COVID-19 has been declared as a global pandemic by the World Health Organisation and this deadly infectious disease has already taken many lives including a huge damage on the global economy. The Covid-19 and the nationwide lockdown forced to shut many businesses including the educational institutions. This forced closedown leads many higher education institutions to move to a different direction and explore a new avenue of the teaching and learning. Not all universities were familiar with a full online delivery and thus required many to adopt the new normal way of delivery. Rieley [1] stated in his research that, these circumstances taught us realise the scenario to make urgent and contingency planning which was very much needed in academic institutions. While considering the online delivery and online learning there are several issues comes in front which includes: online pedagogy, e-learning, lifelong learning and so on. E-learning has been considered as one of the most effective, accessible, flexible and ways of learning. According to Clark and Mayer [2] e-learning is defined as instructions delivered on a digital device such as a computer or mobile that supports learning. They also believed that e-learning increases personal learning by optimising the learning objectives and improving the organisations bottom-line goals (profit maximization). E-learning can also be defined as by answering the questions "how" the course is digitalised so it can be stored in electronic form. In this research, we have aimed to explore few e-learning theories and models and try to find how this impacts the teaching and learning during this Covid-19 pandemic period.

\section{LITERATURE REVIEW \\ Learning Pedagogy and approach}

Learning is depending on the pedagogy used and applied which varies mostly with the use and application. Most of us are using teaching and learning pedagogies according to the need of modules delivery in line with the subject endorsement. We use the pedagogy required and effective to our learners and the effectiveness of the pedagogy often depends on the particular subject matter to be taught, on understanding the diverse needs of different learners, and on adapting to the on-the-ground conditions in the classroom and the surrounding context. On the other hand, the cognitive perspective analyses the shift of the theoretical aspect of learning where the research
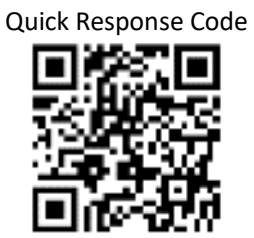

Journal homepage:

https://crosscurrentpublisher.com
Copyright (C) 2021 The Author(s): This is an open-access article distributed under the terms of the Creative Commons Attribution 4.0 International License (CC BY-NC 4.0) which permits unrestricted use, distribution, and reproduction in any medium for noncommercial use provided the original author and source are credited.

Citation: Afzal Sayed Munna \& Anupam Mazumdar (2021). Online Learning: A View from Higher Education. Cross Current Int J Peer Reviewed J Human Soc Sci, 7(2), 4549. 
evidenced that perception, language, thinking and rationale reasoning impact the individual's learning and concept formation processes. In class, general discussion with BA and certificate level students, the researcher found that the knowledge acquisition is the results of the relationship between the new experience the students encounter and the structures for understanding platform has been created by the institution. And thus, building a conceptual framework for understanding becomes a cognitive challenge. The theory of Piaget is mostly significant in this context that conceptual development occurs through intellectual activity rather than information absorption, which was argued by Brown et al. [3] by stating that we learn by understanding the concept as tools which is delivered through instruction.

\section{Learning on Higher Education}

The implementation of learning in higher education must be different from secondary and primary education. Students in college are adults with their complexities as humans. Four assumptions underlie the theory of education for adults, according to Knowles in Andragogical Theory [4], among others are "(1) Changes in self-concept, (2) the role of experience, (3) readiness to learn, and (4) orientation to learning". The assumption changes in the self-concept are defined as "a person grows and matures his self-concept moves from one of total dependency (as is the reality of the infant) to one of increasing self-directedness."

The assumption of self-concept changes (Changes in Self-Concept) is that as a person who grows and matures, his self-concept moves from a person who is dependent to someone who increases his self-authority, and psychologically, he becomes an adult. In this condition, a psychological need arises to be perceived by others as a person who has authority over him and, if he is in a situation that is not by his self-concept, a bad reaction will arise, namely hatred and resistance. The conditions mentioned above are the background for student behaviour. According to Knowles [17], "They have largely resolved their identity-formation issues; they are identified with an adult role. Any experience that they perceive as putting them in the position of being treated as children is bound to interfere with their learning".

The second assumption states that as an adult person, "... he accumulates an expanding reservoir of experience that causes him to become an increasingly rich resource for learning, and at the same time provides him with a broadening base to which to relate new learnings" (p.45). Referring to this, the teacher's role in teaching includes packaging audio-visual presentations and providing reading references to support discussions, laboratory practice, simulations, field experiences, project teams, and other learning action techniques. Optimizing student experience in learning is a must because it will also mean ignoring themselves as individuals if they ignore their experiences.

The third assumption states that an adult, his readiness to learn will reduce his biological development and academic pressure and increase his developmental tasks required for his social role development performance. That is, "learners are ready to learn those things they" need "to because of the developmental phases they are approaching in their roles as workers, spouses, parents, organizational members and leaders, leisure time users, and the like." (p. 47). The implication is the importance of timing to match (coincide) implementing the learning experience with the students' developmental tasks. In his observations, "... a good deal of professional education is totally out of phase with the students' readiness to learn."

The fourth assumption says that children have been conditioned to achieve subject objectives in each lesson, while adults tend to solve each lesson's problems. This difference is the basis for differences in results from a time perspective. From the perspective of children's learning time, the subjects studied in elementary school have little effect on better preparation for adulthood, but as preparation for better learning at an advanced level and last until high school. Meanwhile, adults learn today so that they can be applied to tomorrow. This assumption has a profound impact on the organization of the curriculum and its learning experience.

In the view of constructivism, students play an active role in "building" their understanding. Knowledge cannot be seen as something permanent and free outside the students. Peters, Cornu, and Collins [5] say that learning is a process of accommodation or adaptation based on new experiences or ideas. The constructivist approach requires students to be active and confident in themselves and their abilities. Lecturer support in learning is critical to help students construct the knowledge they develop. Bruner [6] said that "The teacher's skills in establishing learning conversations with and amongst students is also fundamental to the construction of knowledge." This statement is also emphasized by Peters, Cornu, and Collins [5] that "learning conversations allow students and teachers to identify prior learning and exploit the difference between what is already known and what might be constructed as new knowledge." Thus, learning tasks should be student-centred or at least provide opportunities for students to make choices.

\section{Learning Challenges on Higher Education}

The development of Information and Communication Technology (ICT) has increased competence to achieve success in the current knowledge-based economy. Global changes with 
educational liberalization have demanded educational institutions to produce quality students who can compete competitively to be accepted by the market. This demand to meet market needs will ultimately encourage our educational institutions to be more characterized by a knowledge-based economy institution. Punie et al., [7] say, "There is evidence that ICT positively influences educational achievements." Furthermore, there is evidence that educational achievement is positively influenced by ICT (ICT). However, these findings state the ICT available in schools and the ICT obtained by students outside the school.

The implication of the knowledge-based economy era is the tendency to increase services for service and information products, innovative industries, educated workers who can respond to complex problems flexibly, communicate effectively, manage information, and work in teams, generate knowledge. New skills and demands for the mastery of advanced skills. This implication requires creative policies in the delivery of education and the development of the learning process in order to produce learning outcomes as expected. Pope [4] defines creativity as "the application of knowledge and skills in new ways to achieve a valued goal," where according to him; there are four keys to the quality of creativity, namely:

1. The ability to identify new problems, rather than depending on others to define them.

2. The ability to transfer knowledge gained in one context to another in order to solve a problem.

3. A belief in learning as an incremental process, in which repeated attempts will eventually lead to success; and

4. The capacity to focus attention on the pursuit of a goal or set of goals.

In connection with the policies above, Hargreaves, Lieberman, Fullan, and Hopkins [8] note several themes in the focus of national education policies in several countries, including:

1. Standards-based measures to improve attainment in essential outcomes, especially numeracy and literacy.

2. Reporting, assessment, and accountability based on key performance indicators.

3. Increasing post-compulsory participation by expanding higher education and creating new schoolwork pathways and higher vocational qualifications.

4. Reshaping the educational workforce to emphatic flexibility, professional development, specialization of professional and preprofessional roles, and performance management.

From the various focus themes of education policy mentioned above, it can be interpreted that various countries have prepared their nations to be ready to compete openly in this knowledge-based economic era.

\section{The Shift of Learning Paradigm on Higher Education}

Nichols [9] describes the four principles of 21st-century learning. Namely, instruction should be student-centered learning; education should be collaborative; learning should have context, and schools should be integrated with society. Learning development should use a learner-centered learning approach. Students are placed as teach subjects who actively develop their interests and potential. They are no longer required to listen and memorize material but try to construct their knowledge and skills according to their capacity and level of thinking development while being invited to solve real problems in society. Studentcentered learning does not mean giving up learning control entirely to students. Intervention is still needed, and educators act as facilitators who try to help link the prior knowledge that students already have with the new information they will learn. Provide opportunities for students to learn by their learning styles and styles and encourage them to be responsible for the learning process. Also, educators act as guides, who try to help students when they encounter difficulties constructing their knowledge and skills.

Learning will not mean much if it does not impact the lives of students outside campus. Therefore, the study material needs to be linked to the daily life of students. Educators develop learning methods that allow students to connect with the real world. The teacher helps students find value, meaning, and belief in learning and applying it in their daily lives. Educators carry out an assessment of students' performance related to the real world.

To prepare students to become responsible citizens, the campus should facilitate students to be involved in their social environment. Among other things, the existence of community service activities. Students can be involved in various development programs in the community, such as health, education, environmental programs, and more. With the power of technology and the internet, students today can do more. The social space for students is no longer only around the campus or where they live but can reach people in various parts of the world. Education needs to help students become responsible digital citizens.

\section{METHODOLOGY}

The research study is conducted in descriptive way and tried to address the learning approaches in higher education sector, including the concept of online learning and will highlight some common obstacle faced. The data was analysed using the content analysis. It also considered the secondary sources' systematic review, including authors pervious publications, 
journals, websites, other scholarly articles, and academic research publications.

\section{DISCUSSION}

In the traditional view, the concept of learning in higher education is always described through face-toface meetings between lecturers and students that take place in the lecture hall or the classroom. In this context, class has a meaning as a place where lecturers and students meet face to face in the same room. Inglis et al., [10] emphasized that according to traditional concepts, students will get the best education on campus through particular (teaching) methods. The concepts and methods used in the learning process are increasingly gaining competition along with the development of new technologies that allow separate interactions between lecturers and lecturers, between students and students, between lecturers and students, and between students and education providers. In terms of traditional concepts, the interaction between lecturers and students is described as occurring directly. When a student asks something to the lecturer, the relevant lecturer can also answer questions directly from the student.

The new paradigm that has emerged related to the learning process that no longer describes face-toface meetings in the classroom - even though the concept of social interaction in it is maintained - has now been widely accepted and has greatly influenced and impacted human life. The presence of Internet technology makes it easy for people to interact without being bound by time and space anymore. The term cyberspace, which is often used in science fiction stories and describes the virtual world, is now often used to denote various aspects of everyday life related to computers and the internet. The use of e-mail, chatting via the internet, the existence of discussions and participation of individuals and groups in virtual communities are all part of the innovations that occur in today's post-modern era [11]. This innovation also encourages the education sector to enter a completely new era marked by society's ability to form a new civilization that is so dependent on information (technology) and various activities (which become) virtual. Higher education activities that are so difficult to reach, rigid, closed, lacking motivation, and unfriendly, now with the use of the internet known as eLearning has become an option and a source of learning in facing future challenges. Through e-learning, the learning process can take place anywhere. Teachers and students, lecturers and students, tutors and tutors (tutorial participants) no longer need to meet face to face in the lecture hall. Thus, nowadays, it is possible to develop education through advanced technology and produce graduates who are creative and productive and not merely money-oriented. Higher education, therefore, must change society's image from an institution that is considered exclusive to a populist institution that serves the wider community [10].

The Covid-19 Pandemic seems to force the world of education to switch from a traditional learning system to a more modern learning system. The implementation of online learning requires lecturers and students to have the skills to use devices such as laptops and smartphones in learning. They are also required to be skilled in selecting and using the information on the internet that is relevant to the material being discussed. If so far, lecturers have only relied on projectors and PowerPoint slides in teaching; then during the Covid-19 Pandemic, lecturers had to use other learning media by online learning. Lecturers must be able to use various Learning Management Systems (LMS) that can adequately convey material to students, as well as design assessment methods that can measure student learning outcomes in an online learning environment.

On the other hand, students are also required to be able to take advantage of the devices they have for learning. Suppose so far, they have used smartphones only for communication and entertainment purposes, during the Covid-19 pandemic. In that case, students must be able to use their smartphones for learning purposes, for example, communicating with lecturers or sending assignments through electronic mail applications and instant messaging applications such as WhatsApp. They should also be able to use their smartphones to take virtual classes that can be accessed through online learning applications. Learning during the Covid-19 pandemic reduces the use of conventional learning media and maximizes the use of more technologically advanced devices. Both lecturers and students can use smartphones or laptops with internet connections in the learning process. According to Herrington and Herrington [12], the use of mobile technology in universities has increased. Devices currently have connectivity that supports access to materials available on the web so that many students, especially in developing countries, use it as a support tool to take part in online learning Ei-Hussein et al. [13]. Gikas \& Grant [14] adds that by using mobile technology such as smartphones and tablet computers, students can access lecture material and communicate with lecturers and peers wherever they are. A survey conducted by ECAR in 2012 showed that $67 \%$ of students believe that mobile devices play an essential role in their academic activities.

\section{CONCLUSION}

It is inevitable that to cope with this unprecedented time the world has faced educational institutions preparing a well devised contingency plan to deal with such situations. Huang et al. [15] stated that, it is a duty of the institution to ensure the reliability and sufficient availability of information communication technology infrastructure, learning 
tools, digital learning resources in the form of Massive Open Online Courses, e-books, e-notes, and so on are of utmost importance in such severe situations. On the other hand, Martin [16] suggested that while imparting online education the institution should ensure the five distinct elements which include instruction, content, motivation, relationships, and mental health. Pedagogical and technical competency of online educators is of utmost importance. Rigorous quality management programs and continuous improvement are pivotal for online learning success and making people ready for any crisis-like situation.

\section{ACKNOWLEDGEMENT}

Funding: There is no funding used for this research

Conflicts of interest/competing interests: There is no conflict of interest/competing interests

Consent to publish: We both provide consent to publish once approved.

Availability of data and material: N/A

Code availability: N/A

Authors' contribution: Both authors contributed equally on the research/literature review/proof reading and referencing.

\section{REFERENCES}

1. Rieley, J. B. (2020). Corona Virus and its impact on higher education. Research Gate.

2. Clark, R.C., \& Mayer, R.E. (2003). E-learning and the science of instruction: Proven guidelines for consumers and designers of multimedia learning. San Francisco, California: John Wiley \& Sons, Incorporated.

3. Brown, J. S., Collins, A., \& Duguid, P. (1989). Situated cognition and the culture of learning. Educational researcher, 18(1), 32-42.

4. Pope, R. (2005). Creativity - Theory, History, Practice. by Routledge. 2 Park Square, Milton Park, Abingdon,

Oxon, http://elibrary.bsu.az/books_400/N_134.pdf

5. Peters, J., Cornu, Rosie, Le., Collins, J. (2003). Towards Constructivist Teaching and Learning: A Report on Research Conducted in Conjunction with the Learning to Learn Project, November 2003. www.learningtolearn.sa.edu.au/tfel/files/.../learning_t o_lear n_report.doc

6. Bruner, J. (1996). The Culture of Education, London: Harvard University Press.

7. Punie, Y., Zinnbauer, D., \& Cabrera, Marcelino. (2006). A Review of the Impact of ICT on Learning. Working Paper prepared for DG EAC, October 2006. JRC Technical Notes. JRC European Commission and Institute for Prospective Technological Studies (IPTS).
8. Hargreaves, A., Lieberman, A., Fullan, M., \& Hopkins, D. (Eds.). (2010). Second international handbook of educational change (Vol. 23). Springer Science \& Business Media.

9. Nichols, Jennifer, R. (2013). 4 Essential of $21 \mathrm{st}$ Century Learning. http://www.teachthought.com/learning/4-essentialrules-of 21 st-century-learning/

10. Inglis, A., Ling, P., \& Joosten, V. (1999). Delivering Digitally: Managing the transition to the knowledge media. London: Kogan Page.

11. Cuthell, J.P. (2002). Virtual Learning: The Impact of ICT on the Way Young People Work and Learn. Singapore: Ashgate Publishing Co.

12. Herrington, A., \& Herrington, J. (2017). Authentic mobile learning in higher education. International Educational Research Conference. https://doi.org/10.1109/ICNICONSMCL.2006.103

13. El-Hussein, M. O. M., \& Cronje, J. C. (2010). Defining mobile learning in the higher education landscape. Educational Technology and Society.

14. Gikas, J., \& Grant, M. M. (2013). Mobile computing devices in higher education: Student perspectives on learning with cell phones, smartphones \& social media. Internet and Higher Education. https://doi.org/10.1016/j.iheduc.2013.06.002

15. Huang, R. H., Liu, D. J., Tlili, A., Yang, J. F., Wang, H. H., Zhang, M., Lu, H., Gao, B., Cai, Z., Liu, M., Cheng, W., Cheng, Q., Yin, X., Zhuang, R., Berrada, K., Burgos, D., Chan, C., Chen, N. S., Cui, W., Hu, X. (2020). Handbook on facilitating flexible learning during educational disruption: The Chinese experience in maintaining undisrupted learning in COVID-19 outbreak. Smart Learning Institute of Beijing Normal University.

16. Martin, A. (2020). How to optimize online learning in the age of coronavirus (COVID-19): A 5-point guide for educators.

https://www.researchgate.net/publication/339944395 How_to_Optimize_Online_Learning_in_the_Age_of_ Coronavirus_COVID-19_A_5

Point_Guide for_Educators

17. Knowles, M. (1973). The Adult Learner: A Neglected Species. American Society for Training and Development, Madison, Wis. Gulf Publishing Company, P.O. Box 2608, Houston, TX 77001.

18. Gordon, Aber and Berliner. Changing paradigms for education. The Gordon Commission on the Future of Assessment in Education http://www.gordoncommission.org

19. Jarvis, P. (2001). Universities as Institutions of Lifelong Learning: Epistemological Dilemmas. Journal of Higher Education Outreach and Engagement, 6(3), 23.

20. Miller, H. (2006). PARADIGM SHIFT - How Higher Education is Improving Learning. https://www.hermanmiller.com/content/dam/hermanm iller/documents/research_summaries/wp_LearningPar adigm.pdf. 